\title{
The Chilean Strawberry (Fragaria chiloensis): Over 1000 Years of Domestication
}

\author{
Chad E. Finn' \\ U.S. Department of Agriculture, Agricultural Research Service, Horticultural Crops Research Unit, \\ 3420 NW Orchard Avenue, Corvallis, OR 97330 \\ Jorge B. Retamales and Gustavo A. Lobos \\ Centro de Mejoramiento y Fenómica Vegetal, Facultad de Ciencias Agrarias, \\ Universidad de Talca, Casilla 747, Talca, Chile
}

\begin{abstract}
James F. Hancock
Department of Horticulture, College of Agriculture and Natural Resources, Michigan State University, A288 Plant \& Soil Science Building, East Lansing, MI 48824
\end{abstract}

Additional index words. Mapuche, Picunche, Fragaria $\times$ ananassa, Ecuador, white-fruited

\begin{abstract}
The cultivated strawberry of South America, the octoploid Fragaria chiloensis, has a long and interesting history. Although the origin of the species in Chile has not been completely determined, it may have been introduced from North America by birds. After making landfall in Chile, the species spread from the coast into the mountains eventually developing four biotypes. At least two native peoples, the Mapuche, between Rio Bío-Bío and south-central Chile, and the Picunche, between Rio Itata and Rio Bío-Bío, began the domestication process. Although white- and red-fruited forms were domesticated, the white form (likely because of its fruit size) may have been preferred because the red-fruited types are not mentioned as frequently in the literature. At the time of the Spanish invasion of Chile, $F$. chiloensis was widely grown in small garden plots. Under the Spanish rule, larger plantings, first of 1 to 2 ha and later of many hectares, were grown. As the Spanish continued their exploration and conquest of South America, they carried $F$. chiloensis with them up the western coast to Perú and Ecuador. For many years these scattered plantings were the source of fresh fruit for the burgeoning human populations. The cultivated $F$. Xananassa was introduced in $C$ hile $\approx 1830$ but $F$. chiloensis was still preferentially grown. In the early 1900s, a large canning industry emerged serving hundreds of acres of $F$. chiloensis. By the $1950 \mathrm{~s}, F$. Xananassa began to predominate and the rise in importance of the University of California and Europeandeveloped cultivars displaced much of the traditional $F$. chiloensis production. An increased awareness of this vast native Chilean genetic resource arose in the 1980s and 1990s. Scientists at the Universidad de Talca, associated with USDA-ARS Plant Exploration Office-sponsored trips to Chile, and with El Instituto de Investigaciones Agropecuarias-Cauquenes in Chile have collected and characterized germplasm that represents not only tremendous diversity, but captures many of the land races that have been developed. This germplasm has been used in small commercial plantings $(0.1$ to 0.3 ha) and in breeding programs to further develop $F$. chiloensis commercial cultivars. A small but vibrant community of small growers, particularly in Chile and Ecuador, produce the land races for commercial sale in local markets. Approximately 30 to 40 ha of open-field plantings are cultivated in Chile with yields averaging $\approx 3$ to 4 tons/ha. The selected $F$. chiloensis genotypes and collected clones from the wild have served as a valuable source of germplasm in modern breeding programs and the development of new cultivars with the white color and aromatic flavor typical of some of the traditional selections well underway.
\end{abstract}

\section{HISTORY}

The cultivated strawberry (Fragaria ×ananassa Duch. ex Rozier) originated from an accidental cross of the white-fruited Chilean strawberry $[F$. chiloensis (L.) Mill. subsp. chiloensis f. chiloensis] and the meadow strawberry ( $F$. virginiana Mill. subsp. virginiana) that occurred in a Royal Botanical Garden in France (Darrow, 1966; Staudt, 1999). Fragaria virginiana is an octoploid $(2 n=8 x=56)$ species native throughout much of North America where there is sufficient moisture. Fragaria virginiana's movement to Europe

Received for publication 25 Jan. 2013. Accepted for publication 5 Mar. 2013.

This paper was part of the workshop "A Survey on the Contribution of Indigenous People of North America to Horticulture" held 1 Aug. 2012 at the ASHS Conference, Miami, FL, and sponsored by the History of Horticultural Science Working Group (HIST).

${ }^{1}$ To whom reprint requests should be addressed; e-mail Chad.Finn@ARS.USDA.gov. cannot be pinpointed to a single event or person; rather, it seems to have occurred many times from the settlers from present-day Virginia up to those along the St. Lawrence River and may have occurred as early as when Jacques Cartier explored this region in 1523 (Darrow, 1966; Wilhelm and Sagen, 1974). On the other hand, the colorful history of the journey of $F$. chiloensis, also an octoploid, to Europe is well described (Fig. 1; Darrow, 1966; Wilhelm and Sagen, 1974). Fragaria chiloensis is native to the fog belt along the Pacific Ocean from Alaska through British Columbia to the central California coast and as a disjunct distribution in Chile along the Pacific Ocean and into the Andes Mountains from lat. $35^{\circ} 30^{\prime} \mathrm{S}$ to long. $47^{\circ} 33^{\prime} \mathrm{S}$ and between sea level and $1850 \mathrm{~m}$ elevation (del Pozo and Lavín, 2005; Lavín et al., 2000). Migrating birds are presumed to have carried seeds from the North American to South American coast. Once established on the Chilean coast, the species moved inland and differentiated into different forms, often taking on the phenotype of $F$. virginiana growing inland in North America.
In Chile, the mouth of the Biobio River is near current-day Concepción. The native people in this region, the Picunche, to the north of the Biobio River, and the Mapuche, to the south of the Biobio, cultivated strawberries more than 1000 years ago (Hancock et al., 1999). The Picunche, who were largely an agrarian society, were believed to have taught the Mapuche, who were primarily huntergatherers, about agriculture, including strawberry cultivation. Further to the north, the invading Incas either received or took superior plants from the Picunche to grow in their gardens. The fruit in each of these cultures were consumed fresh, dried, or prepared as medicines (De Moesbach, 1992). Like other cultures with access to native sweet fruits, the people fermented juice of the strawberry. Labarca (1994) reported that the Mapuche's favorite fermented drink (lahueñe mushca) was made from the small, red-fruited native strawberry called "llahuen" or "lahueñe." Although there were many uses for the small red form, over time two distinct cultivated types began to stand out: a large white and an improved, but not necessarily large, red form. 


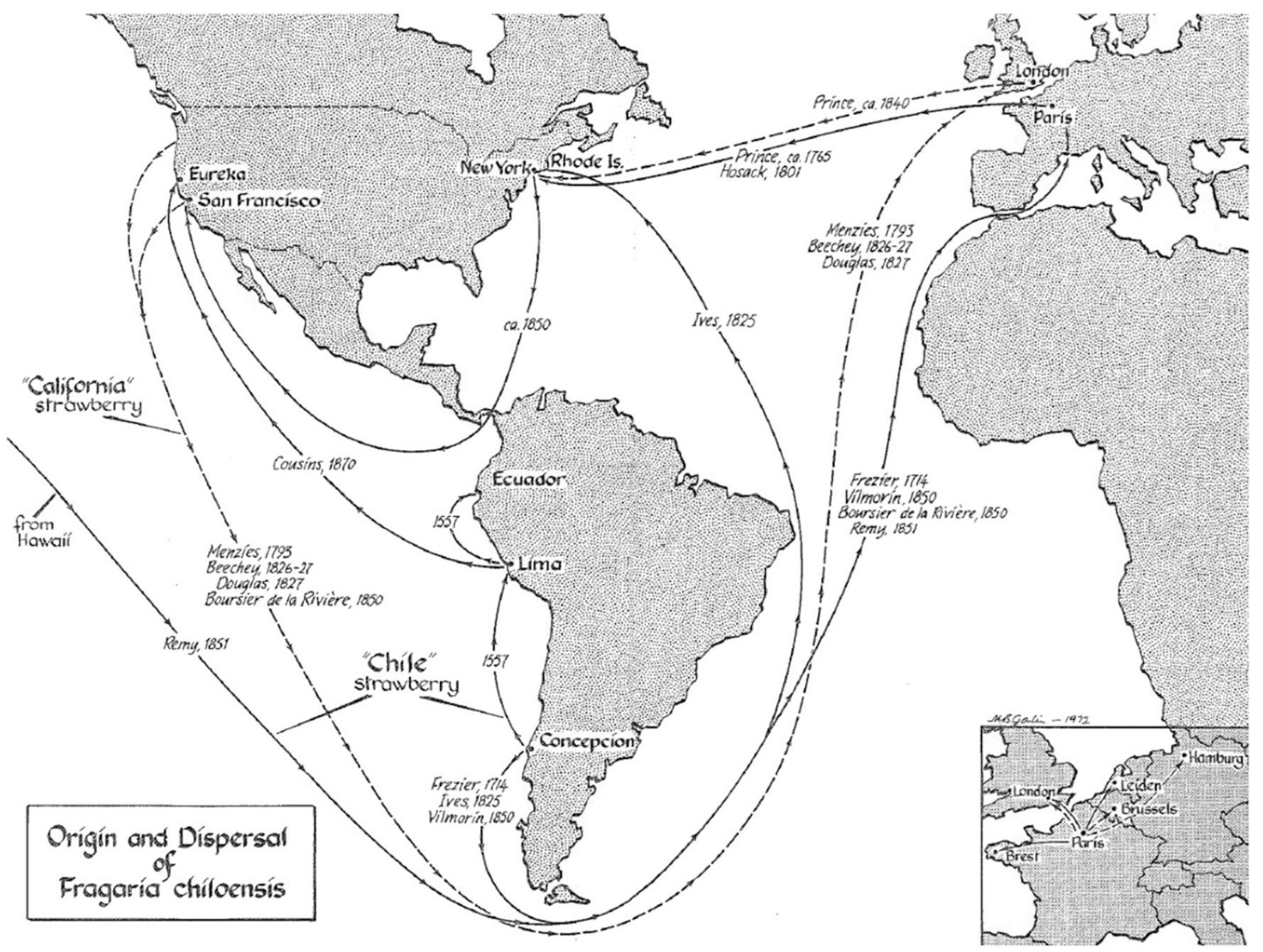

Fig. 1. Origin and dispersal of Fragaria chiloensis (Wilhelm and Sagen, 1974).

Although relatively uncommon, native white forms have been found in multiple sites in southern Chile (Hancock et al., 1999). Larger and larger selections of the white form ended up dominating the cultivated types and when comparisons of the modern $F$. Xananassa cultivated types and the land race types are made, the modern types genotypically align with the white forms (Hancock et al., 1999; Hokanson et al., 2006; Lavin, 1997) more closely than with North American $F$. chiloensis. Apparently, whereas strawberries were well known as a native crop and they were commonly grown in garden plots by the native peoples, there was not a concerted effort to cultivate them in large quantities.

When the Spaniards invaded western South America, they came into conflict with the Mapuche in 1536, who kept them largely north of the Bío-Bío River until the 1880s. The large elite strawberries were considered a bounty of conquest and moved with the Spaniards north to Cuzco, Perú in 1557, and to Ecuador before 1789 (Popenoe, 1921). During the colonial period, strawberry production on a somewhat larger scale (1 to 2 ha) began to take place near Renca, just north of Santiago (Hancock et al., 1999). Surprisingly, although the Chilean strawberries were introduced to Perú in 1557, and although they were noted by explorers, it took until 1712 for these superior clones to be introduced to Europe from Chile (Darrow, 1966; Popenoe, 1921). Amédée Francois Frézier, an engineer in the French Army Intelligence Corps, was commissioned by King Louis XIV of France to conduct a reconnaissance mission to Chile and Perú. The King was apparently determined to keep his grandson on the Spanish throne and therefore wanted to know as much as possible about all parts of the Spanish empire (Darrow, 1966). Although not a botanist, Frézier, "had the botanist's impulse for collecting" and collected unusually large-fruited strawberry plants that he transported back to France (Fig. 2; Darrow, 1966). As the story goes, he nursed the plants carefully with limited water on the six-month voyage and returned with five plants to Marseille (Popenoe, 1921). Frezier gave two plants to the ship's owner, one plant to the Royal Garden, one to the minister of fortifications, and he kept one for himself (Popenoe, 1921).

Most evidence points to strawberries having been primarily a garden crop for the native Chileans, but during the Spanish colonial period, there were larger 1- to 2-ha plots of cultivated types raised in coastal valleys from west of Chillán (lat. $36^{\circ} 34^{\prime} 0^{\prime \prime} \mathrm{S}$ ) to the Isle of
Chiloé (lat. $41^{\circ} 40^{\prime} \mathrm{S}$ to $43^{\circ} 40^{\prime} \mathrm{S}$ ) (Hancock et al., 1999). Most production was geared toward local markets until the early 1900 s and fruit was usually transported to the markets by mule. Popenoe (1921) famously commented on the quality of the 1920 cultivars grown in the United States to the native types that had been taken from Chile and planted in Huachi, Ecuador (lat. $0^{\circ} 18^{\prime} \mathrm{S}$ ): "What sorts have we, may I ask, which could be thrown into boxes holding 30 to 35 quarts, carried seven or eight miles on mule back, worked over by hand and packed in two to six-quart baskets, and then shipped down to a tropical seaport, there to be kept in the market for two to three days at a temperature of 70 to 85 degrees? Even with such treatments as this, the Guachi strawberry (ed. Huachi/Guachi is a small community near Ambato, Ecuador) holds up well. Retaining its shape and texture to an extent altogether unknown among northern strawberries."

As canning technology developed around the world, a large canning industry using $F$. chiloensis developed near Nueva Imperial, Chile (lat. 38 $43^{\prime} 59^{\prime \prime} \mathrm{S}$ ) and a somewhat smaller one near Corral, Chile (lat. 39 $52^{\prime} 02^{\prime \prime} \mathrm{S}$ ) between 1900 and 1950. In the mid-1990s, cultivars from Europe and from the United States began to displace the native strawberry (Hancock 
et al., 1999). Although the circumstances are unknown, the breeding records for the USDAARS, Horticultural Crops Unit indicate that in 1947 and 1948, selections from the USDAARS program, OSC 2074, OSC 2127, and OSC 2138, were named 'Quillan', 'Maullin', and 'Ancud', respectively, in Chile (unpublished USDA-ARS breeding records). Like with so many places around the world, the meteoric rise of the California strawberry industry led to California cultivars being adopted around much of the world and Chile was no exception. Most of Chile as well as Perú and Ecuador, where the native $F$. chiloensis was once such an important part of production, are now planted in genotypes that trace their pedigree to California germplasm and are grown using the same annual, plasticulture system developed in California. Nonetheless, small pockets of production of pink- and white-fruited genotypes of $F$. chiloensis production have held on in places like Curepto (lat. $35^{\circ} 08^{\prime} \mathrm{S}$ ), Putú (lat. $35^{\circ} 13^{\prime} \mathrm{S}$ ), Curanipe (lat. $35^{\circ} 50^{\prime} \mathrm{S}$ ), Chovellén (lat. $35^{\circ} 53^{\prime} \mathrm{S}$ ), Contulmo (lat. $38^{\circ} 00^{\prime} \mathrm{S}$ ), Purén (lat. $38^{\circ} 01^{\prime} \mathrm{S}$ ), Puerto Saavedra (lat. $38^{\circ} 46^{\prime} \mathrm{S}$ ), and the Island of Chiloé (lat. $41^{\circ} 40^{\prime} \mathrm{S}$ to $43^{\circ} 40^{\prime} \mathrm{S}$ ), Chile; Cuzco (lat. 13 $3^{\circ} 45^{\prime}$ S), Peru; and Huachi Grande (lat. $1^{\circ} 18^{\prime}$ S), Ecuador (Finn et al., 1998; Lavín et al., 2000).

\section{CURRENT PRODUCTION}

There has been in increasing interest in expanding production of $F$. chiloensis in Chile to find a niche in the market as well as to take advantage of a resurgent interest in new crops (Table 1; Retamales et al., 2005). This expansion is hampered by selections/land races that are low-yielding and, when compared with our modern cultivars, very soft, small, and tenderskinned with a very short shelf life. Traditional production systems have ranged from fields where plants are relatively evenly spaced in all directions, as might be found in Ecuador today, to systems very comparable to traditional matted row systems (Finn et al., 1998). Researchers are exploring whether improvements in irrigation, fertilization, pest control, or perhaps environmental modification using high tunnels or greenhouse, maybe with hydroponics, might expand the production season and provide significant improvement in yield and fruit quality over the traditionally or currently used systems. Currently, the $F$. chiloensis genotypes grown in Chile have a range of skin color from almost white to slightly red. When these are grown in tunnels with ultraviolet-filtering plastic, the fruit are whiter than they would be if grown in openfield production. The crop is sold mostly fresh to markets no more than $70 \mathrm{~km}$ away. Some fruit is shipped as far as Santiago (Chile) from the more southern production areas, but most of the fruit that leaves the production region is processed as jams or spreads for pastries and the lowest quality material fruit is mixed with white wine to create a very aromatic and refreshing drink.

Commercial Chilean $F$. chiloensis fields are concentrated near Putú (lat. $35^{\circ} 13^{\prime} \mathrm{S}$,

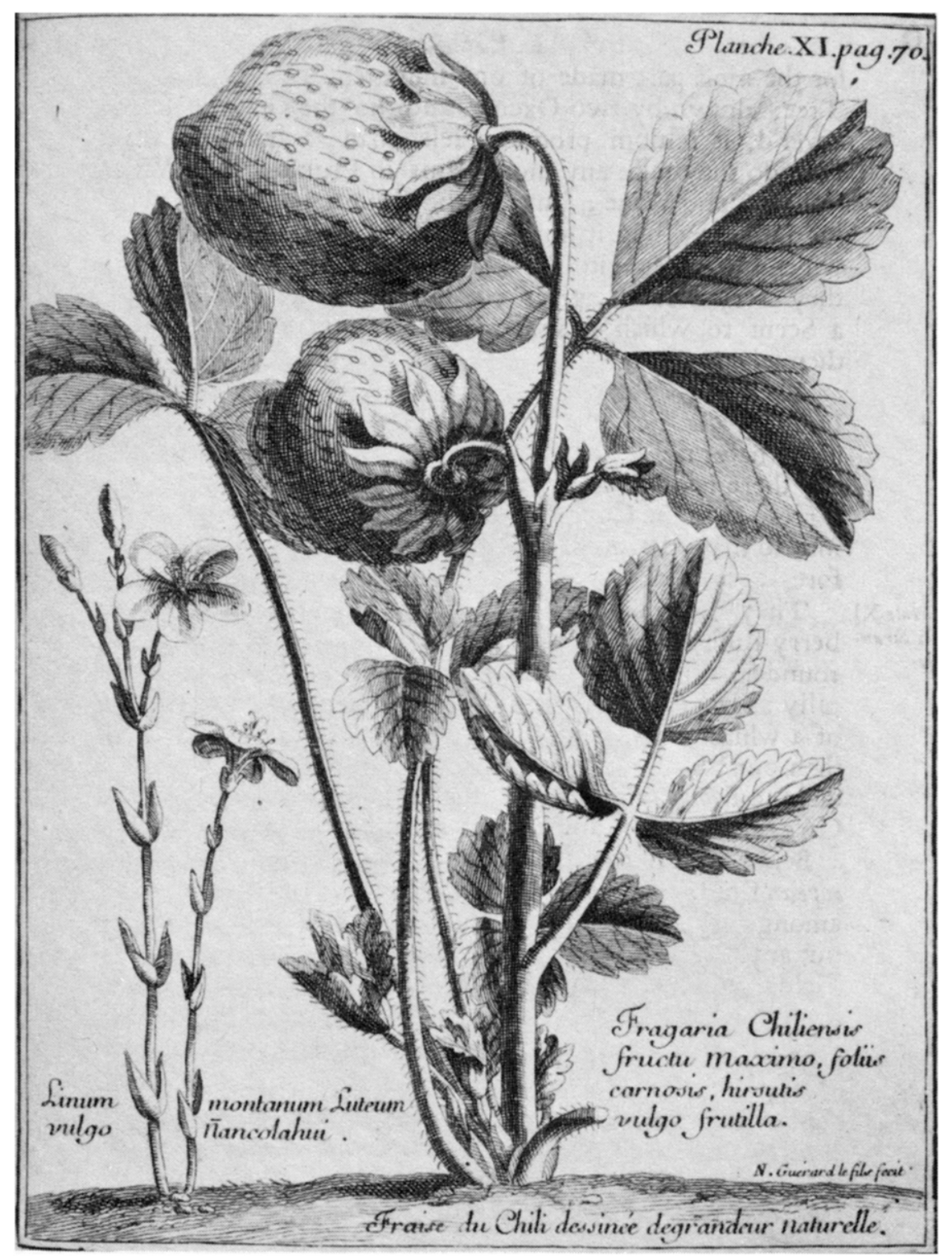

Fig. 2. Fraise du Chili or Frutilla. From A. Frézier (1717), A voyage to the South Seas and along the coasts of Chile and Peru in the years 1712, 1713, and 1714 as reproduced in Wilhelm and Sagen (1974).

Table 1. Comparison of Chilean native strawberry and commercial strawberry (FAOSTAT, 2013; Hancock, 1999).

\begin{tabular}{lcc}
\hline Item & Fragaria $\times$ ananassa & F. chiloensis \\
\hline World area planted (ha) & 280,000 & $75-80$ \\
Yield (tons/ha) & $50-70$ & $3-5$ \\
Length of harvest season (month) & $3-6$ & $1-2$ \\
Planting duration (years) & $1-2$ & $6-8$ \\
\hline
\end{tabular}

Región del Maule), Contulmo (lat. $38^{\circ} 00^{\prime} \mathrm{S}$; Región del Bío-Bío), and Purén (lat. $37^{\circ} 35^{\prime}$ S; Región de la Araucanía). Fields are established using runners harvested from a grower's own plantings, leading to potential problems with moving viruses and other diseases into new fields. Plantings usually last five to eight years before they are replanted. Most plantings are less than 0.1 ha in size with a total estimated of 30 to 40 ha in Chile. Plantings established from lat. 35 to $36^{\circ} \mathrm{S}$, where rainfall is typically 500 to $600 \mathrm{~mm}$, are irrigated, whereas those from lat. 37 to $42^{\circ} \mathrm{S}$, where 900 to $1200 \mathrm{~mm}$ of rainfall is more common, are usually not irrigated. The nutrient program primarily consists of manure applications, although calcium carbonate is applied to soils where the $\mathrm{pH}$ is too low for good production. The leading disease problems are strawberry leaf spot (Ramularia tulasnei Sacc.), powdery mildew (Oidium $\mathrm{sp}$.), and several viruses. Other than diseases, aphids (primarily Chaetosiphon fragaefolii Cockerell) and snails (primarily Helix aspersa O.F. Muller) are the predominant pests. Expansion of production of $F$. chiloensis is desirable 
but faces problems with low plant availability, poor nursery plant quality (including an accumulation of viruses), low yields, and the lack of a structured market to distribute this unique crop. The marketing model being used for the white-fruited strawberry called pineberry in Europe offers a marketing model that may be applicable in Chile (<http://www. vitalberry.eu/pineberries/>).

\section{CURRENT USES IN BREEDING}

The Universidad de Talca (Chile) has an ongoing breeding effort toward developing white- and pink-fruited, pure $F$. chiloensis types for the export market. This work is based primarily on germplasm collected by scientists sponsored by the USDA-ARS Plant Exploration Office to collect in Chile (Cameron et al., 1991, 1993; Lavin, 1997; Lavín et al., 1993) and who were accompanied by researchers from El Instituto de Investigaciones Agropecuarias-Cauquenes (Lavín et al., 1993). At the beginning of this century, this work was expanded by collections done by the Universidad de Talca (Retamales et al., 2005), who in collaboration with C.E. Finn (USDAARS, Corvallis, OR) gathered germplasm from southern Chile (lat. 39 to $43^{\circ} \mathrm{S}$ ). From those germplasm collections, several pure $F$. chiloensis crosses using white- and redfruited parents were made to develop improved selections from this species. The Universidad de Talca plans to release three $F$. chiloensis cultivars in 2013 with white-, pink-, or salmoncolored fruit. The tragic earthquake in 2010 destroyed much of the university's laboratories and germplasm collections (in vitro and potted material) and progress on different research areas has been slowed. The USDA-ARS (Corvallis, OR) continues to work on developing white-fruited, pure $F$. chiloensis types as well as working with Michigan State University in recreating $F$. ×ananassa with a much broader germplasm base than the original source.

In 1996, the 'Huachi Grande' clone of $F$. chiloensis was collected on a commercial farm near Huachi Grande (Finn et al., 1998). This genotype has been used extensively in the USDA-ARS Corvallis and Michigan State University breeding programs and was presumed to be similar to, or the same, genotype as Darrow's 'Ambato' (Darrow, 1952). Darrow had used 'Ambato' in crosses in the USDAARS Beltsville program but very little seems to have come of that effort (Darrow, 1966).

This genotype was growing on volcanic, extremely well-drained soils. It cyclically ripened fruit that were large by "wild" standards but were in the 7- to 10-g size range in the off-season. The fruit of 'Huachi Grande' was pinkish white, soft, and had a tender skin but the fruit are extremely aromatic with a very nice flavor. 'Huachi' does not survive outdoors in Michigan as a result of cold temperatures and struggles but lives through Oregon's very wet winters. When used in crosses with adapted germplasm, selections that are very large ( 20 to $30 \mathrm{~g}$ ) with adaptation, fair yield, and fruit that are flavorful but soft can readily be selected in the first generation hybrids between $F$. chiloensis and F. Xananassa.

Hancock et al. (2001a, 2001b) identified other outstanding $F$. chiloensis clones for the strawberry "supercore" group of 38 elite genotypes that represents the diversity present in $F$. chiloensis and $F$. virginiana. This "supercore" has since been extensively evaluated and used for germplasm enhancement, especially as part of the cultivated strawberry reconstruction project (Hancock et al., 2001a, 2001b, 2005, 2008, 2010; Stegmeir et al., 2010). PI 236579, PI 551746, and PI 602567, in addition to 'Huachi Grande' (PI 612318), that trace to Chilean heritage have been particularly valuable parents and their genes are in advanced selections for commercial trial (USDA-ARS, National Clonal Germplasm Repository, 2013).

One of the amazing genetic resources contributed to the world from South America has been $F$. chiloensis. A critical component of the cultivated strawberry, it is still important as a cultivated species and as a source or terrific germplasm for breeding modern strawberries.

\section{Literature Cited}

Cameron, J.S., C.H. Shanks, Jr., T.M. Sjulin, and C. Muñoz. 1991. Collection of Fragaria chiloensis in central and southern Chile, p. 108110. In: Dale, A. and J.J. Luby (eds.). The strawberry into the 21 st century. Timber Press, Portland, OR.

Cameron, J.S., T.M. Sjulin, J.R. Ballington, C.H. Shanks, C. Muñoz, and A. Lavin. 1993. Exploration, collection, and evaluation of Chilean Fragaria: Summary of 1990 and 1992 expeditions. Acta Hort. 348:65-74.

Darrow, G.M. 1952. The Ambato strawberry of Ecuador. Fruit Var. and Hort. Dig. 8:53-54.

Darrow, G.M. 1966. The strawberry. Holt, Rinehart, and Winston, New York, NY.

De Moesbach, E.W. 1992. Botánica indígena de Chile. Andrés Bello, Santiago, Chile.

del Pozo, and A. Lavín. 2005. Distribution and ecotypic differentiation of Fragaria chiloensis in Chile. HortScience 40:1635-1636.

FAOSTAT. 2013. 12 Jan. 2013. <http://faostat3. fao.org/home/index.html\#HOME>.

Finn, C.E., J.F. Hancock, and C. Heider. 1998. Notes on the strawberry of Ecuador: Ancient land races, the community of farmers and modern production. HortScience 33:583-587.

Hancock, J.F. 1999. Strawberries. CABI Publ., New York, NY.

Hancock, J.F., P.W. Callow, A. Dale, J.J. Luby, C.E. Finn, S.C. Hokanson, and K.E. Hummer. 2001a. From the Andes to the Rockies: Native strawberry collection and utilization. HortScience 36:221-225.

Hancock, J.F., C.E. Finn, S.C. Hokanson, J.J. Luby, B.L. Goulart, K. Demchak, P.W. Callow, S. Serce, A.M.C. Schilder, and K.E. Hummer. 2001b. A multi-site comparison of native octoploid strawberries from North and South America. J. Amer. Soc. Hort. Sci. 126:579586.

Hancock, J.F., C.A. Drake, and P.W. Callow. 2005. Genetic improvement of beach strawberry. HortScience 40:1644-1645.

Hancock, J.F., C.E. Finn, J.J. Luby, A. Dale, P.W Callow, and S. Serce. 2010. Reconstruction of the strawberry, Fragaria $\times$ ananassa, using native genotypes of $F$. virginiana and $F$. chiloensis. HortScience 45:1006-1013.

Hancock, J.F., A. Lavin, and J.B. Retamales. 1999. Our southern strawberry heritage: Fragaria chiloensis of Chile. HortScience 34:814 816.

Hancock, J.F., T.M. Sjulin, and G.A. Lobos. 2008. Strawberries, p. 393-437. In: Hancock, J.F. (ed.). Temperate fruit crop breeding: Germplasm to genomics. Springer, New York, NY.

Hokanson, K.E., M.J. Smith, A.M. Connor, J.J Luby, and J.F. Hancock. 2006. Relationships among subspecies of New World octoploid strawberry species, Fragaria virginiana and Fragaria chiloensis, based on simple sequence repeat marker analysis. Can. J. Bot. 84:18291841.

Labarca, E. 1994. Butamalón. Editorial. Universitaria y Fondo de Cultura Económica. Santiago, Chile.

Lavin, A. 1997. Caracterización botánica, fisológical y agronómica de ecotipos chilenos de Fragaria chiloensis (L.) Duch., recolectados en las X y XI Regiones de Chile. Informe final, Proyecto Fondecyt 1940083

Lavín, A., A. Del Pozo, and M. Maureira. 2000. Distribución de Fragaria chiloensis (L.) Duch. En Chile. Plant Genet. Resourc. 122:24-28.

Lavín, A., C. Muñoz, J.R. Ballington, and J.S. Cameron. 1993. Collección de Fragaria chiloensis L. en la X y XI regions de Chile. Simiente (Chile) 63:18-20.

Popenoe, W. 1921. The frutilla, or Chilean strawberry. J. Hered. 12:457-466.

Retamales, J.B., P.D.S. Caligari, B. Carrasco, and G. Saud. 2005. Current status of Chilean native strawberry and the research needs to convert the species into a commercial crop. HortScience 40:1633-1634.

Staudt, G. 1999. Systematics and geographic distribution of the American strawberry species. University of California Press, Berkeley, CA.

Stegmeir, T.L., C.E. Finn, R. Warner, and J.F. Hancock. 2010. Performance of an elite strawberry population derived from wild germplasm of Fragaria chiloensis and $F$. virginiana. HortScience 45:1140-1145.

USDA-ARS, National Clonal Germplasm Repository. 2013. National Plant Germplasm System. Washington, DC. 28 Feb. 2013. <http://www. ars-grin.gov/npgs/acc/acc_queries.html>.

Wilhelm, S. and J.E. Sagen. 1974. A history of the strawberry from ancient gardens to modern markets. University of California Div. of Agr. Sci., Berkeley, CA. 